Eventos 



\title{
Psicologia como instrumento de produção de subjetividades
}

\author{
Bruna Velásquez, Estevão Oliveira de Paula, \\ Felippo do Nascimento Mota Lima, Lilian Monteiro Alfaia, \\ Myriam de Carvalho Monteiro, Pedro Halbritter*, Fernanda Bueri, \\ Iara Baptista e Marcos Roitman ${ }^{* *}$ e Arthur Arruda Leal Ferreira ${ }^{* * * *}$
}

Por que existem tantas orientações psicológicas, não concordando os psicólogos nem quanto à definição da psicologia? Para compreender essa situação supõe-se que no campo psicológico se cruzam um conjunto de experiências oriundas de nossas práticas sociais cotidianas (práticas confessionais, disciplinares etc.) com diversos conceitos extraídos das ciências naturais (adaptação, informação etc.). Essas práticas sociais, agora ungidas pelo poder da verdade científica, retornam sobre os sujeitos, impondo-se a eles como sua verdade última. O objetivo deste trabalho é poder estudar empiricamente essa produção de subjetividades gerada pelo poder de verdade embutido nas práticas psicológicas. Para tal, foram constituídos alguns questionários de sondagem submetidos ao comitê de ética em pesquisa da UFRJ e aplicados a estudantes do ensino médio, assim escolhidos por encontrarem-se num período em que não há ainda uma especialização profissional, apesar de já se esperar uma ampla difusão dos dados gerais de uma cultura psicológica. Com o primeiro questionário, pretendeu-se testar a concordância dos sujeitos, em função da posição do enunciador do discurso. A hipótese proposta era de que enunciação de uma sentença, variando através do proferimento de diferentes atores sociais como religiosos, políticos e psicológicos, teria, perante estes últimos atores, a maior probabilidade de ser reconhecida como verdadeira, uma vez que proferida por representantes do discurso científico. Com o segundo questionário procurou-se determinar a imagem do psicólogo em relação a outros profissionais como médicos, advogados e engenheiros. Para isso, foi pedido que os sujeitos citassem cinco características de cada uma das profissões acima e da psicologia. Já com terceiro questionário tentou-se detectar a existência de um "senso comum psicológico", dado no contraste da avaliação entre proposições de cunho psicológico, cientificista e esotérico, observando com quais os sujeitos mais concordariam. Com o quarto questionário, realizado à maneira do experimento anterior, esboçou-se uma avaliação da psicologia do senso comum a partir da consideração de certos casos, tomando-os no contraste com as interpretações das principais orientações psicológicas (psicanálise, humanismo, behaviorismo e cognitivismo). Os resultados, de modo geral, apontaram para uma clara adesão

\footnotetext{
Alunos da graduação do Instituto de Psicologia da Universidade Federal do Rio de Janeiro.

* Estudantes de segundo grau do Colégio de Aplicação da UFRJ.

*** Professor do Instituto de Psicologia da Universidade Federal do Rio de Janeiro; End: Rua Riachuelo, ñ: 169, Apto: 405, Centro, Rio de Janeiro, RJ. CEP: 20.230-014. E-mail: arleal@ superig.com.br
} 
aos enunciados proferidos por psicólogos (independente do conteúdo destes), além da escolha por enunciados psicológicos em detrimento dos demais tipos. Assim, a primeira sondagem empírica apontou para uma preferência pelas sentenças emitidas pelo psicólogo; a terceira sondagem empírica demonstrou que a freqüência com que as afirmativas com teor psicológico foram tidas com opinião favorável, foi significativamente maior, em detrimento das outras afirmativas; e a quarta sondagem empírica apontou para uma ligeira preferência pelas afirmativas com teor psicanalítico. Por fim, cabe destacar que esta sondagem dos processos de subjetivação gestados pelas psicologias é apenas um primeiro esboço de uma linha de pesquisa que necessita ser aperfeiçoada, engendrando novas sondagens empíricas.

Apoio Financeiro: FAPERJ / FUJB 